\title{
Computed tomography image of the mediastinal and axillary lymph nodes in clinically sound Rottweilers ${ }^{1}$
}

\author{
Ana Carolina B. Fonseca Pinto ${ }^{2 *}$, Elisângela Aneli ${ }^{3}$, Andreza C. Patara ${ }^{4}$, Carla A.B. \\ Lorigados $^{5}$, Gabriela Paola R. Banon ${ }^{6}$ and Claudia Figueiredo ${ }^{7}$
}

\begin{abstract}
Fonseca Pinto A.C.B., Aneli E., Patara A.C., Lorigados C.A.B., Banon G.P.R. \& Figueiredo C. 2013. Computed tomography image of the mediastinal and axillary lymph nodes in clinically sound Rottweilers. Pesquisa Veterinária Brasileira 33(3):405-410. Departamento de Cirurgia, Faculdade de Medicina Veterinária e Zootecnia, Universidade de São Paulo, Av. Prof. Dr. Orlando Marques de Paiva 87, Cidade Universitária, São Paulo, SP 05508-701, Brazil. E-mail: anacarol@usp.br

Trough computed tomography (CT), it is possible to evaluate lymph nodes in detail and to detect changes in these structures earlier than with radiographs and ultrasound. Lack of information in the veterinary literature directed the focus of this report to normal aspects of the axillary and mediastinal lymph nodes of adult dogs on CT imaging. A CT scan of 15 normal adult male and female Rottweilers was done. To define them as clinically sound, anamnesis, physical examination, complete blood count, renal and hepatic biochemistry, ECG, and thoracic radiographs were performed. After the intravenous injection of hydrosoluble ionic iodine contrast medium contiguous $10 \mathrm{~mm}$ in thickness thoracic transverse images were obtained with an axial scanner. In the obtained images mediastinal and axillary lymph nodes were sought and when found measured in their smallest diameter and their attenuation was compared to musculature. Mean and standard deviation of: age, weight, body length and the smallest diameter of the axillary and mediastinal lymph nodes were determined. Mean and standard deviation of parameters: age $3.87 \pm 2.03$ years, weight $41.13 \pm 5.12$, and body length $89.61 \pm 2.63 \mathrm{~cm}$. Axillary lymph nodes were seen in $60 \%$ of the animals, mean of the smallest diameter was $3.58 \mathrm{~mm}$ with a standard deviation of 2.02 and a minimum value of $1 \mathrm{~mm}$ and a maximum value of $7 \mathrm{~mm}$. From 13 observed lymph nodes $61.53 \%$ were hypopodense when compared with musculature, and $30.77 \%$ were isodense. Mediastinal lymph nodes were identified in $73.33 \%$ of the dogs; mean measure of the smallest diameter was $4.71 \mathrm{~mm}$ with a standard deviation of $2.61 \mathrm{~mm}$ and a minimum value of $1 \mathrm{~mm}$, and a maximum value of $8 \mathrm{~mm}$. From 14 observed lymph nodes $85.71 \%$ were isodense when compared with musculature and $14.28 \%$ were hypodense. The results show that it is possible to visualize axillary and mediastinal lymph nodes in adult clinically sound Rottweilers with CT using a slice thickness and interval of $10 \mathrm{~mm}$. The smallest diameter of the axillary and mediastinal lymph nodes not surpassed $7 \mathrm{~mm}$ and $8 \mathrm{~mm}$ respectively. Their attenuations were equal or smaller than that of musculature in the post contrast scan.
\end{abstract}

INDEX TERMS: Lymph nodes, measurement, computed tomography, dogs, Rottweiler.

\footnotetext{
${ }^{1}$ Received on August 8, 2012

Accepted for publication on January 22, 2013.

${ }^{2}$ Departamento de Cirurgia, Faculdade de Medicina Veterinária e Zootecnia (FMVZ), Universidade de São Paulo (USP), Avenida Prof. Dr. Orlando Marques de Paiva 87, Cidade Universitária, São Paulo, SP 05508-701, Brazil. *Corresponding author: anacarol@usp.br

${ }^{3}$ Médica Veterinária autônoma, Mestre pelo Departamento de Cirurgia, Faculdade de Medicina Veterinária e Zootecnia (FMVZ), Universidade de São Paulo (USP), São Paulo, SP.
}

\footnotetext{
${ }^{4}$ Médica Veterinária autônoma, Doutora pelo Departamento de Cirurgia, FMVZ-USP, São Paulo, SP.

${ }^{5}$ Pós-Doutoranda, Departamento de Cirurgia, FMVZ-USP, São Paulo. E-mail: clorigados@usp.br

${ }^{6}$ Médica Veterinária, Doutora pelo Departamento de Cirurgia, FMVZ-USP, São Paulo, SP.

${ }^{7}$ Médica Radiologista, Fleury Medicina e Saúde, Rua Dr. Diogo de Faria 1077, Apto 102, Vila Clementino, São Paulo, SP 04037-003, Brazil. E-mail: claudia.figueiredo@grupofleury.com.br
} 
RESUMO.- [Imagem por tomografia computadorizada dos linfonodos axilares e mediastinais de cães rottweilers clinicamente saudáveis.] A tomografia computadorizada é uma modalidade diagnóstica que possibilita a avaliação detalhada dos linfonodos e que é capaz de detectar mais precocemente alterações envolvendo estas estruturas, que modalidades de imagem como a radiografia e a ultrassonografia. Tendo em vista a escassez de informações na literatura veterinária esta pesquisa objetivou fornecer informações sobre os aspectos tomográficos normais dos linfonodos axilares e mediastinais em cães. Realizou-se o exame tomográfico de 15 cães adultos, machos e fêmeas, da raça Rottweiler, selecionados como clinicamente normais por meio de anamnese, exame físico, hemograma, perfil bioquímico renal e hepático, eletrocardiograma e exame radiográfico do tórax. Após a injeção intravenosa do contraste iodado hidrossolúvel iônico, realizaram-se cortes tomográficos transversais do tórax com $10 \mathrm{~mm}$ de espessura e $10 \mathrm{~mm}$ de incremento em um tomógrafo axial. Os exames tomográficos foram avaliados buscando-se identificar os linfonodos axilares e mediastinais. Quando visibilizados, os linfonodos foram mensurados em seu menor eixo e sua atenuação foi comparada com a da musculatura. Foram calculados a média e desvio padrão da idade, do peso, do comprimento dos animais e do menor eixo dos linfonodos axilares e mediastinais. A média de idade dos animais e o desvio padrão foram de 3,87 anos $\pm 2,03$, do peso foi de $41,13 \mathrm{~kg} \pm 5,12$ e do comprimento dos animais foi de $89,61 \mathrm{~cm} \pm 2,63$. Os linfonodos axilares foram visibilizados em $60 \%$ dos animais, a média das mensurações dos menores diâmetros e o desvio padrão foi de $3,58 \mathrm{~mm} \pm 2,02$ com valor mínimo de $1 \mathrm{~mm}$ e máximo de $7 \mathrm{~mm}$. Dos 13 linfonodos observados 61,53\% apresentaram-se hipoatenuantes comparativamente a musculatura e $30,77 \%$ isoatenuantes. Os linfonodos mediastinais foram observados em 73,33\% dos cães, a média das mensurações dos menores diâmetros e o desvio padrão foi $4,71 \mathrm{~mm} \pm 2,61$ com valor mínimo de $1 \mathrm{~mm}$ e máximo de $8 \mathrm{~mm}$. Dos 14 linfonodos observados $85,71 \%$ apresentaram-se isoatenuantes comparativamente a musculatura e $14,28 \%$ apresentaram-se hipoatenuantes. A partir deste estudo confirmou-se que em cães da raça Rottweiler os linfonodos axilares e mediastinais podem ser visibilizados ao exame tomográfico em cortes de 10 milímetros de espessura com igual incremento. Seus diâmetros menores não ultrapassaram $7 \mathrm{~mm}$ no referente aos linfonodos axilares e $8 \mathrm{~mm}$ para os mediastinais, e sua atenuação foi iso ou hipoatenuante em relação à musculatura no exame pós-contraste.

TERMOS DE INDEXAÇÃO: Linfonodos, mensuração, tomografia computadorizada, cães, Rottweiler.

\section{INTRODUCTION}

Diagnostic imaging modalities in veterinary medicine have significantly increased their abilities in the last decade. Conventional radiology and ultrasound are already well-defined diagnostic modalities, whereas computer tomography, magnetic resonance and nuclear medicine are methods that just begin that used in animals, seeking to increment the diagnosis.
Radiographic examination is still a valuable diagnostic modality through the evaluation of the thoracic cavity in veterinary medicine, specially, in small animal medicine (Roberts \& Banks 1972, Burk 1983, Schwarz \& Tidwell 1999). It allows a whole study of the pulmonary fields, mediastinal structures, pleura, pleural space, skeleton bone and soft tissue, and it has been largely used in order to search for metastases in thoracic cavity (Suter et al. 1974, Suter 1984).

As the cost of acquisition and maintenance of these equipments are high, computed tomography image for animals is primacy of the large research center. Computed tomography is a sectional image, free from overlap of the adjacent structures and can be produced along transverse, dorsal, sagittal and oblique sections. All of the techniques of images that produce section slices, such as ultrasound, computed tomography and magnetic resonance, for example, are a type of tomography (Tidwell 1999). Hence, the computed tomography is a method of diagnosis by image that produces section slices of body region, using X-ray and a computer, with the advantage over the conventional radiography, once it has higher sensibility to small differences of X-ray attenuation and it is free from structure superimposition (Tidwell 1992, Hathcock \& Stickle 1993, Schwarz \& Tidwell 1999).

Careful study of the thoracic cavity, using computed tomographic examination, allows the evaluation of pulmonary fields, mediastinal structures, pleura, pleural space and thoracic walls (Suter et al. 1974, Burk 1991, DeHaan et al. 1991, Feeney et al. 1991, Stickle \& Hathcock 1993, Jakovljevic \& Morrison 1998). DeHaan et al. (1991) recommended, in veterinary clinic, the use of the computed tomography scan to detect pathologic processes involving hilary and mediastinal lymph nodes, to search small and multiple nodes, to guide node aspiration, using slender needle when fluoroscophy is not available, and to detect and measure precociously pulmonary metastasis. More recently, MR imaging was evaluated as a method that may help distinguish metastatic from non-metastatic lymph nodes (Pokorny et al. 2012).

On computed tomography images, the lymph nodes are visualized as small structures, with round or elliptical aspect and with attenuation of soft tissue surrounded by fat tissue (Webb 2000, Petite \& Kirberger 2011). They can be differentiated from vessels through their localization in contrasted exam and their attenuation. When the lymph nodes can be visualized, they should be measured by their short axis, since this measurement best express the effective diameter of the lymph node and displays less variation in normal patients (Webb 2000).

According to Burgener \& Kormano (1998), in man, the axillary lymph nodes normally have diameter at most of $1 \mathrm{~cm}$, but they assert that nodules slightly larger can be occasionally found inner healthy person. However, for these authors, if the axillary lymph nodes measured $1.5-2.0 \mathrm{~cm}$, this would suggest an inflammatory process (reactive hyperplasia) or an early sign of cancer, whereas nodules larger than $2 \mathrm{~cm}$ would be indicative of metastatic disease or lymphoma. Concerning mediastinal lymph nodes, Burgener \& Kormano (1998) affirm that a diameter of 0.3- 
$0.6 \mathrm{~cm}$ is expected for them and they are in the visibility limit. The authors consider that only mediastinal nodules with a diameter larger than $1 \mathrm{~cm}$ can be reliably evaluated, and they recognize them as altered mainly because of their horizontal and diagonal direction along the bronchial tubes and pulmonary vessels. Webb (2000) asserts that, in man, inner mammary, paracardiac and paravertebral lymph nodes normally are not visible with computer tomography scan in healthy patients, nevertheless, in other mediastinal regions, normal lymph nodes can be identified by computed tomography scan.

For man, the upper limit allowed for the short axis of different mediastinal lymph nodes has been established; but generally speaking, for clinical purposes, excepted in subcarinal region, the short axis, measuring at most $1 \mathrm{~cm}$ are considered normal (Burgener \& Kormano 1998, Webb 2000). Webb (2000) also affirms that, in an inflammatory process or an infiltration by cancer, the lymph nodes can be together appear like a tumor, and mediastinal fat tissue can be replaced by opacity of the soft tissue. However, the meaning of increased lymph node needs to be carefully interpreted; in other words, it is very important to relate the changes in this structure to the medical history of the patient, since this enlargement can be related to metastatic events, but could also be a direct result of an hyperplasic or inflammatory process (Webb 2000).

According to Holliday \& Reede (2003), based in works by Mancuso et al. (1983a,b), many centers accept as adequate some characteristics to evaluate the lymph nodes: in the vast majority of cases, they cannot be visualized with computed tomography scan; when it is possible to visualize them, they must have an ovoid shape, homogeneous attenuation with density of soft tissue and they need to measure at most $1 \mathrm{~cm}$ in diameter; any normal lymph node never must measure more than $1.5 \mathrm{~cm}$, this could represent a reactive or neoplastic process. Independent from its size, any intra parenchymal hypo attenuation is considered abnormal, and when there is obliteration of fat adjacent to them, this can represent an extra nodal spread from a tumor or postsurgical or post radiotherapy inflammation. Palaoni et al. (2006) reported the importance of contrast enhancement of the tracheobronchial lymph node in dogs with diagnosis of a primary lung tumor. They reported that even with minimal lymph node enlargement, when they present significant contrast enhancement, homogeneous or ring like, abnormality should be considered.

Kneissl \& Probst (2006) documented the magnetic resonance imaging appearance of normal lymph nodes of the head and neck in the dog. Symmetry, signal intensity, homogeneity and size, as well as relation to the surrounding fat were noted. For animals, with respect to axillary and mediastinal lymph nodes, the upper limits of their diameters were not still established (Fonseca Pinto 2003).

Hence, considering the relevance of malignant tumours in the veterinary clinic, the importance of cancer search and complete lack of information in the veterinary literature about the usual computed tomographic aspects of the mediastinal and axillary lymph nodes, it is indispensable to develop studies that seek supply data about normally tomographic aspects of these lymph nodes and to provide subsidies for an adequate interpretation of the images. The goal of this study was to evaluate size, localization and attenuation of mediastinal and axillary lymph nodes in healthy dogs using computed tomography.

\section{MATERIALS AND METHODS}

Fifteen healthy mature, males and females Rottweiler, coming from the kennel of Second Battalion of Armed Forces, were used for the study. To define them as clinically normal, anamnesis (considering the data of identification as age, sex, weight and body length(crown-rump), physical examination, completely blood count, renal and hepatic blood biochemistry profiles, electrocardiographic and thoracic radiographic examination were made.

The dogs were previously sedated with acepromazine ${ }^{8}$, at dosages ranging from 0.05 to $0.1 \mathrm{mg} / \mathrm{kg}$ of body weight (BW), and meperidine ${ }^{9}$ hydrochloride, at dosages ranging from 3.0 to $5.0 \mathrm{mg} / \mathrm{kg} \mathrm{BW}$, both given intramuscularly. After 20 minutes, cephalic vein was catheterized for intravenous fluid and drug administration and the animals were anesthetized with propofol ${ }^{10}$ at a rate of $0.5 \mathrm{mg} / \mathrm{kg} \mathrm{BW}$, administered intravenously. When animals exhibited clinical signals like mandibular muscle relaxation and absence of laryngeal and pharyngeal reflexes, a proper endotracheal tube was inserted. Then, the dogs were immediately connected to a standard circle anesthetic machine ${ }^{11}$, which delivered of isoflurane $\mathrm{e}^{12}$ in $100 \%$ oxygen. Anesthesia was maintained with an adequate concentration of isoflurane that could allow maintenance of the second or third anesthetic plan. Cardiac and respiratory rates, cardiac output ${ }^{13}$ and non-invasion systemic arterial pressure were carefully monitored during this anesthetic procedure.

Computed tomographic scans of thoracic cavity were obtained using axial CT unit (CT-MAX $640^{14}$ ). Images from all dogs were printed on Kodak Ektanscan $\mathrm{M}^{15} \mathrm{X}$-ray films of size $35 \mathrm{x} 43 \mathrm{~cm}$ and an automatic X-ray film processor, from RPX-OMAT Processor ${ }^{16}$, was used develop these films. The patients were positioned in sternal recumbency on the computed tomographic scanning table with thoracic limbs extended cranially, to avoid their superimposition on thoracic cavity. Transverse computed tomographic images were performed from the beginning of the thorax up to the aortic arch region, in order to visualize mediastinal and axillary lymph nodes.

Settings for the computed tomographic image technique were as follows: $120 \mathrm{kV}$ and 55 to $77 \mathrm{~mA}$. Image acquisition time was 3 minutes for each study. Slice thickness was $10 \mathrm{~mm}$ with an increment of $10 \mathrm{~mm}$. Once an appropriated volume of $1.5 \mathrm{ml} / \mathrm{kg}$ of BW of an ionic iodine contrast agent (Urografina $2922^{\circledR 17}$ ) had been injected intravenously, the computed tomographic images were obtained. The administration of contrast was made according to the following protocol: $2 / 3$ of the total volume of contrast agent was injected in bolus, approximately at rate $1.0 \mathrm{ml} / \mathrm{kg}$ of BW and the residual volume was applied under continuous injections (drip

\footnotetext{
${ }^{8}$ Acepran ${ }^{\circledR}$ in $0.2 \%$ - Univet S.A.

${ }^{9}$ Dolantina - Cristália, São Paulo, SP.

${ }^{10}$ Diprivan - Zeneca, São Paulo, SP.

${ }^{11}$ Samurai III - Takaoka, São Paulo, SP.

${ }^{12}$ Isoforine - Cristália, São Paulo, SP.

${ }^{13}$ System for monitoring DX2010 - Dixtal, São Paulo, SP.

${ }^{14}$ General Eletric.

${ }^{15}$ Brazilian KODAK Com. Ind. Ltda.

${ }^{16}$ Eastman Kodak Company.

${ }^{17}$ Schering of Brazil, Chemical and Pharmaceutical Industry Ltda.
} 
without occurrence of continuous flow). Computed tomographic images were reviewed using a soft-tissue setting with adequate window width and level, according to the values proposed by Burk (1991), Stickle \& Hathcock (1993), and Schwarz \& Tidwell (1999). In the obtained computed tomographic images, mediastinal and axillary lymph nodes were searched. When they were recognized, they were measured in their smallest diameter, their attenuations were compared to that of musculature and their anatomic relations were recorded.

Average and standard deviation (SD) of age, weight, body length (crown-rump), size of observed lymph nodes by region and their minimum and maximum respective values were determined. Distributions of these data were tested for normality using the Shapiro-Wilk test. The significance level was set at $\mathrm{P}<0.05$.

\section{RESULTS}

Animals that were submitted to computer tomography examination for axillary and mediastinal lymph nodes evaluation were presented in Table 1 . The median age of the 15 dogs eva-

Table 1. Animals that were submitted to computed tomography examination for axillary and mediastinal lymph nodes evaluation

\begin{tabular}{ccccc}
\hline No & Animals & $\begin{array}{c}\text { Age } \\
\text { (years) }\end{array}$ & $\begin{array}{c}\text { Weight } \\
\text { (kg) }\end{array}$ & $\begin{array}{c}\text { Body lengh } \\
\text { (cm) }\end{array}$ \\
\hline 1 & Logan & 4 & 47 & 93 \\
2 & Thor & 4 & 48 & 85 \\
3 & Orca & 4 & 36 & 89 \\
4 & Gorbi & 3 & 39 & - \\
5 & Osco2 & 1 & 42 & 90 \\
6 & Helga & 7 & 33 & 88 \\
7 & Apollo 22 & 2 & 45 & 92 \\
8 & Apolo & 6 & 47 & 89 \\
9 & Biba & 2 & 36 & 85 \\
10 & Haro & 5 & 45 & 88 \\
11 & Airón & 3 & 42 & 91 \\
12 & Cronos & 5 & 39 & 91 \\
13 & Arthur & 2 & 42 & 91 \\
14 & Osco1 & 2 & 32 & - \\
15 & Roy & 8 & 44 & 93
\end{tabular}

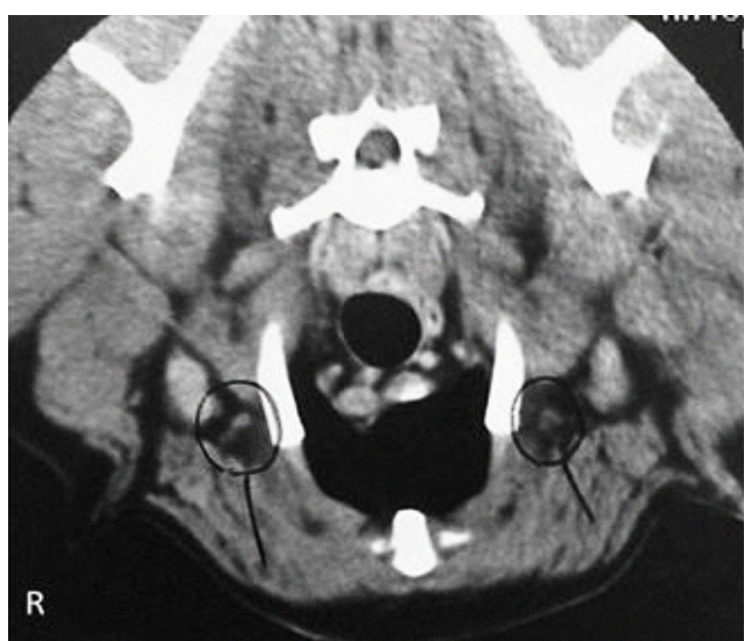

Fig.1. CT transverse image of the cranial mediastinum in a dog number 1 (Logan). The axillary lymph nodes were observed (circles), the right (isodense) and left (hypodense) measures 4 and $7 \mathrm{~mm}$, respectively.
Table 2. Measurement and attenuation of axillary and mediastinal lymph nodes

\begin{tabular}{|c|c|c|c|c|c|}
\hline \multirow[t]{3}{*}{ № } & \multirow[t]{3}{*}{ Animals } & \multicolumn{2}{|c|}{ Axillary lymph node } & \multirow{2}{*}{\multicolumn{2}{|c|}{$\begin{array}{l}\text { Mediastinal } \\
\text { lymph node }\end{array}$}} \\
\hline & & \multirow[t]{2}{*}{ Size (mm) } & \multirow[t]{2}{*}{ Attenuation } & & \\
\hline & & & & Size $(\mathrm{mm})$ & Attenuation \\
\hline 1 & Logan & $4(\mathrm{R})$ & Isodense (R) & 1 & Isodense \\
\hline & & $7(\mathrm{~L})$ & Hypodense (L) & & \\
\hline 2 & Thor & 1 & Hypodense & $7 / 8 / 8$ & Isodense \\
\hline 3 & Orca & - & - & - & - \\
\hline 4 & Gorbi & - & - & - & - \\
\hline 5 & Osco2 & - & - & - & - \\
\hline 6 & Helga & 2 & $\begin{array}{c}\text { Hypodense (L) } \\
\text { Isodense (R) }\end{array}$ & 5 & Isodense \\
\hline 7 & Apollo 22 & - & - & 4 & Isodense \\
\hline 8 & Apolo & $\begin{array}{c}\text { Poorly } \\
\text { defined }<10\end{array}$ & Hypodense & 5 & Isodense \\
\hline 9 & Biba & $5(\mathrm{R})$ & Isodense (R) & 8 & Isodense \\
\hline & & 7 (L) & Hypodense (L) & 3 & Hypodense \\
\hline 10 & Haro & 3 & Isodense & - & - \\
\hline 11 & Airón & 1 & Hypodense & 2 & Isodense \\
\hline 12 & Cronos & 4 & Hypodense & 2 & Hypodense \\
\hline 13 & Arthur & $\begin{array}{c}3(\mathrm{~L}) \\
2 \text { and } 4(\mathrm{R})\end{array}$ & Hypodenses & 5 & Isodense \\
\hline 14 & Osco 1 & - & - & 7 & Isodense \\
\hline 15 & Roy & - & - & 1 & Isodense \\
\hline
\end{tabular}

(R) right, (L) left, - not observed.

luated in this study was 3.87 years $(\mathrm{SD} \pm 2.03$ ), with values at least 1 and at most 8 years. The median weight was $41,13 \mathrm{~kg}$ ( $\mathrm{SD} \pm 5.12$ ), ranging from 32 to $48 \mathrm{~kg}$. The median body length (crown-rump) was $89.61 \mathrm{~cm}(\mathrm{SD} \pm 2.63)$, with a range of 85 $93 \mathrm{~cm}$. All of these parameters had normal distribution.

The Table 2 presents the results of measurements and attenuation of lymph nodes. Axillary lymph nodes were visible, from two sides (Fig.1) or one side (Fig.2), and one or more by side, on the computed tomographic images of nine $(60 \%)$ animals. Normal distribution was also noticed for the smallest diameter of the axillary lymph nodes, with average of 3.58 millimeters $(\mathrm{mm})(\mathrm{SD} \pm 2.02)$ and with minimum and maximum values of 1 and $7 \mathrm{~mm}$, respectively.

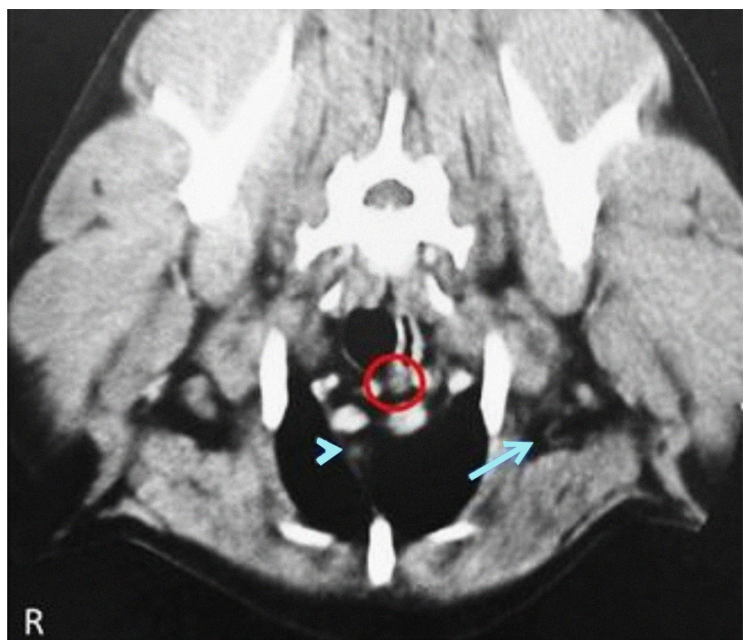

Fig.2. CT transverse image of the cranial mediastinum in a dog number 9 (Biba). The left axillary lymph node is observed hypodense (arrow). Isodense mediastinal lymph node measuring $8 \mathrm{~mm}$ (circle) and another hypodense measuring 3mm (arrow head) were also observed. 
Thirteen axillary lymph nodes were observed. Concerning the attenuation characteristics, a larger number (61.53\%) of axillary lymph nodes observed were hypodense when compared to musculature, and only $30.77 \%$ were isodense.

About mediastinal lymph nodes (Fig.2), they were visible on the computed tomographic images of eleven (73.33\%) animals, and only two dogs (18.18\%) showed a number of mediastinal lymph nodes greater than one. Normal distribution was also noticed for the smallest diameter of the mediastinal lymph nodes, with average of $4.71 \mathrm{~mm}$ (SD equals to 2.61) and with a minimum and a maximum values of 1 and $8 \mathrm{~mm}$, respectively. Fourteen mediastinal lymph were identified. Concerning the attenuation characteristics, $85.71 \%$ were isodense when compared to musculature and only $14.28 \%$ of them were hypodense. Axillary and mediastinal lymph nodes were not identified as hyperdense or showing contrast enhancementt in any of the 15 evaluated dogs. A blur of mediastinal fat was detected in only 2 animals, neither of which showed visible axillary lymph node, but the smallest diameter of their mediastinal lymph nodes measured 1 and $4 \mathrm{~mm}$ and attenuation of these structures was isodense when compared to musculature.

\section{DISCUSSION}

The dogs of this study demonstrated zootecnic and clinical similar characteristics and the experimental group can therefore be considered as homogeneous.

Respecting the personal preference of the observer, the window width and level were selected in order to obtain images that could allow adequate evaluation of the mediastine, according to values proposed by Burk (1991), Stickle \& Hathcock (1993) and Schwarz \& Tidwell (1999).

According to Marincek \& Young (1980), the administration of hydrosoluble iodine contrast facilitated an adequate distinction among mediastinal vascular structures and other images. In this study, a volume of $1.5 \mathrm{ml} / \mathrm{kg}$ of BW of an ionic iodine contrast agent was injected intravenously, according to the following protocol: $2 / 3$ of the total volume was administrated in a bolus injection and then, the remaining volume was applied intravenously under continuous infusion during the time of acquisition of the images.

Slice thickness selected for this report was determined in accordance with the study by Fonseca Pinto et al. (2006) in order to evaluate, with the same generation of scan, the thoracic cavity in animals with more than $30 \mathrm{~kg}$.

As in man, according to Burgener \& Kormano (1998), axillary lymph nodes could be identified in a considerable number of dogs (64.29\%). As the Rottweilers of this study presented smallest diameter of axillary lymph nodes lower than $7 \mathrm{~mm}$, this value might be considered as upper limit for this parameter.

With respect to the attenuation, as in human medicine, according to Mancuso et al. (1983) (1983a,b), axillary lymph nodes attenuation was identified as approximately equal or less than the attenuation of musculature on computed tomographic images and as being homogeneous.
Therefore, a hyperdense lymph node, heterogeneous aspects of them given by the presence of hypo or hyperdense areas thin the parenchyma or a contrast enhancement visualized on computed tomographic scan, can be considered as an evidence of abnormality.

About the number of axillary lymph nodes in this study, at most two lymph nodes were identified at one side. We believe that an increase in number of lymph nodes may represent abnormal characteristic as has been described for humans (Webb 2000).

Mediastinal lymph nodes were observed more frequently than axillary lymph nodes: they could be identified in $73.33 \%(11 / 15)$ of the dogs. The median of the smallest diameter of the mediastinal lymph nodes $(4.85 \mathrm{~mm})$ was similar to that obtained from clinically normal men (from 3 to $6 \mathrm{~mm}$ ) (Burgener \& Kormano 1998). This mediastinal lymph node average was higher than that of the axillary lymph nodes $(3.58 \mathrm{~mm})$. This finding was the opposite of what has been reported previously for humans. They suggest that the value of $10 \mathrm{~mm}$ should be used as upper limit for lymph nodes, especially for mediastinal lymph nodes and proposed that once axillary lymph nodes are assessed at $15 \mathrm{~mm}$, this data might suggest only inflammatory process (Burgener \& Kormano 1998). This diversity of results could be due to a different response to infectious and inflammatory processes, since both can be responsible for lymphadenomegaly, in these species. With respect to attenuation, in the present study the lymph nodes were predominantly identified as isodense and with homogeneous aspect, agreeing with previous medical reports (Mancuso et al. 1983a,b).

As the maximum value of smallest diameter of mediastinal lymph nodes was assessed at $8 \mathrm{~mm}$, it is possible that this result might be used as upper limit for this parameter in Rottweiler. Since any axillary and mediastinal lymph nodes were not identified as hyperdense or with contrast enhancement on computed tomographic images of 15 dogs selected in this study, this implies that these aspects should be relevant when observed. Related to the number of mediastinal lymph nodes, the majority of the dogs, i.e., 9 of 10 animals in which lymph nodes were visualized, presented solitary nodes, implying that, in dogs, the visualization of agglomerated lymph nodes might means abnormality, as it has been proposed in previous medical report (Webb 2000).

Two dogs of this study showed blur of mediastinal fat and this finding, in Medicine, means a relevant change (Webb 2000); nevertheless, in this research, this correlation could not be made, once the animals were previously selected as healthy and no changes in size or amount of mediastinal and axillary lymph nodes were observed. We agree with Webb (2000) who suggested that the findings about increased lymph nodes should be carefully evaluated, considering the history of patient, since this rise might be related to changes from different origins and with distinct prognosis.

Since there is an increasing availability of computed tomography machines for the veterinary practice nowadaysin Brazil as in another countries, it is more and more important to develop studies to better determine protocols 
and normal parameters for adequate evaluation of the the axillary and mediastinal lymph nodes.. Furthermore, objective data as measures, for example, like observed in this study, should not be extrapolated from the human medicine.Instead appropriate values for the veterinary practice should be established considering the diversity among animal species and the different animal size.

\section{CONCLUSIONS}

This study demonstrated that mediastinal and axillary lymph nodes in Rottweiler dogs could be identified on computed tomographic images with slice thickness of $10 \mathrm{~mm}$ and with an equal amount of increment.

The smallest diameter of axillary and mediastinal lymph nodes not surpassed $7 \mathrm{~mm}$ and $8 \mathrm{~mm}$ respectively.

Their attenuation was isodense or hypodense when compared with musculature on contrasted computed tomographic scan, and they should be preferentially identified as isolated structures.

With the use of new generation helicoidal, similar studies to establish protocols of lymph node evaluation should be developed in order to supply technical and normal data that may improve the analysis of computed tomographic findings.

\section{REFERENCES}

Burgener F.A. \& Kormano M. 1998. Coração e mediastino, p.222-245. In: Ibid. (Eds), Diagnóstico Diferencial em Tomografia Computadorizada. Revinter, Rio de Janeiro. 378p.

Burk R.L. 1983. Radiographic examination of the cardiopulmonary system. Vet. Clin. North Am., Small Anim. Pract. 13:241-258.

Burk R.L. 1991.Computed tomography of thoracic diseases in dogs. J. Am. Vet. Med. Assoc. 199:617-621.

De Haan C.E., Papageorges M. \& Kraft S.L. 1991. Radiographic diagnosis (pulmonary mass). Vet. Radiol. 32:75-77.

Feeney D.A., Fletcher T.F. \& Haardy R.M. 1991. Atlas of Correlative Imaging Anatomy of the Normal Dog Ultrasound and Computed Tomography. W.B. Saunders, Philadelphia. 382p.

Fonseca Pinto A.C.B.C., Iwasaki M., Figueiredo C., Cortopassi S.R.G. \& Sterman F.A 2006. Tomografia computadorizada do tórax de cadelas portadoras de neoplasias mamárias malignas. I. Determinação da técnica do exame. Braz. J. Vet. Res. Anim. Sci. 43:95-102.

Hathcock J.T. \& Stickle R.L. 1993. Principles and concepts of computed tomography. Vet. Clin. North Am., Small Anim. Pract. 23:399-415.
Holliday R.A. \& Reede D.L. 2003. Cervical adenopathy and neck masses, p. 75-600. In: Haaga J.A., Lanzieri C.F. \& Gilkeson R.C. (Eds), CT and MR Imaging of the Whole Body. $4^{\text {th }}$ ed. Mosby, St Louis. 1152p.

Kneissl S. \& Probst A. 2006. Magnetic resonance imaging features of presumed normal head and neck lymph nodes in dogs. Vet. Radiol. Ultrasound 47:538-541.

Mancuso A.A., Harnsberger H.R. \& Muraki A.S. 1983a. Computed tomography of cervical and retropharyngeal lymph nodes: normal anatomy, variants of normal and applications in staging head and neck cancer. I. Normal anatomy. Radiology 148:709-714. (Apud Holliday \& Reede 2003)

Mancuso A.A., Harnsberger H.R. \& Muraki A.S. 1983b. Computed tomography of cervical and retropharyngeal lymph nodes: normal anatomy, variants of normal and applications in staging head and neck cancer. II. Pathology. Radiology 148:715-723. (Apud Holliday \& Reede 2003)

Marincek B. \& Young S. 1980. Computed tomography of spontaneous canine neoplasms. Vet. Radiol. 21:181-184.

Petite A. \& Kirgerger R. 2011. Mediastinum, p.249-260. In: Schwarz T. \& Saunders J. (Eds), Veterinary Computed Tomography. Wiley-Blackwell, Hoboken. 557p.

Pokorny E., Hecht S., Sura P.A., Leblanc A.K., Phillips J., Conklin G.A. \& Haifley K.A., Newkirk K. 2012. Magnetic resonance imaging of canine mast cell tumors. Vet. Radiol. Ultrasound 53:167-173.

Palaoni M.C., Adams W.M., Dubielzig R.R., Kurzman I., Vail D.M. \& Hardie R.J. 2006. Comparison of results of computed tomography and radiography with histopatologic findings in tracheobronchial lymph nodes in dogs with primary lung tumors: 14 cases (1999-2002). J. Am. Vet. Med. Assoc. 228:1718-1722.

Roberts R. \& Banks W.C. 1972. Radiographic considerations in the normal and altered cardiac silhouette of the canine patient. Southwest. Vet. 26:11-16.

Schwarz L.A. \& Tidwell A.S. 1999. Alternative imaging of the lung. Clin. Tech. Small Anim. Pract.14:187-206.

Stickle R.L. \& Hathcock J.T. 1993. Interpretation of computed tomographic images. Vet. Clin. North Am., Small Anim. Pract. 23:417-435.

Suter P.F. 1984. Thoracic Radiography: A text atlas of thoracic diseases of the dog and cat. P.F. Suter, Wettswil, Switzerland. 734p.

Suter P.F., Carrig C.B., O’Brien T.R. \& Koller D. 1974. Radiographic recognition of primary and metastatic pulmonary neoplasms of dogs and cats. J. Am. Vet. Radiol. Soc. 15:3-25.

Tidwell A.S. 1992. Diagnostic pulmonary imaging. Problems in Veterinary Medicine 4:239-264.

Tidwell A.S. 1999. Advanced imaging concepts: a pictorial glossary of CT and MRI technology. Clin. Tech. Small Anim. Pract. 14: 65-111.

Webb W.R. 2000. Mediastino: anormalidades linfonodais e massas tumorais, p.34-60. In: Webb W.R., Brant W.E. \& Helms C.A. (Eds), Fundamentos de Tomografia Computadorizada do Corpo. 2a ed. Guanabara Koogan, Rio de Janeiro. 303p. 